\title{
Decision-Making Difficulties of Senior High School Referred Graduates of Cape Coast Metropolis
}

\author{
Ebenezer Appiah ${ }^{1 *}$, Eric Oduro-Ofori ${ }^{1}$, Lucy Effeh Attom ${ }^{2}$ \\ ${ }^{1}$ Department of Planning, College of Built Environment, Kwame Nkrumah University of Science and \\ Technology, Kumasi, Ghana \\ ${ }^{2}$ Department of Social Studies Education, Faculty of Social Sciences Education, University of Education, \\ Winneba, Ghana \\ * Corresponding author: Ebenezer Appiah, E-mail: ebenezerappiah3@gmail.com
}

\begin{abstract}
This research examined the career decision difficulties of Senior High School Referred Graduates (SHSRGs) in the Cape Coast Metropolis. Mixed methods with exploratory design was employed and the data were collected using questionnaire and interview guide. Stratified and random sampling techniques were adopted to select a total of three hundred and sixty (360) SHSRGs. Purposive, convenience and snowball sampling techniques were also used to select six (6) parents, three (3) remedial school teachers and one (1) director of Ghana Education Service (GES) for the study. The result indicated $(189,53.8 \%)$ of the referred graduates usually felt they needed confirmation and support for their decisions about their career choice from a professional or somebody they trust. It was also revealed that $(263,74.3 \%)$ had considered the field they would like to major or the field they would like to choose. Again, $(59,16.7 \%)$ of the referred graduates encountered difficulties in making career decisions because they did not know which occupations interest them whereas $(89,25.0 \%)$ indicated they found it difficult to make career decision because they were focusing on their referred papers. It was recommended that the SHSRGs should make career choices based on guidance and counselling received from experts in various institutions in the metropolis. They should resist imposition of careers by people and accept non-collegiate education through excursions and embrace work surveillance. This will sharpen their understanding about what industry expect from them and connect them to the realities of the world of work.
\end{abstract}

Keyword: Decision-making, Career selection, Decision dynamics, Career failure, Referred graduates, Cape Coast Metropolis, Ghana

DOI: $10.7176 /$ RHSS/10-22-13

Publication date: November $30^{\text {th }} 2020$

\section{INTRODUCTION}

The concept of career has been variously described by social psychologists as an individually mediated response to outside role messages on particular occupational circumstances, such as medicine, engineering, architecture, or teaching for their psychological effect (Ibara, 2004). A study on career choice and how poverty affect people's decision-making process in United Kingdom (UK) by Sheeny-Skeffington and Rea (2017), showed that children growing up in less endowed environment were more likely to choose careers that fulfil the goals of job and financial security. Also, this category of people, low in socio-economic status with financial pressure may accept underpaid job offers at their exploratory stage (15-24 years) over getting higher education with bigger rewards later. Such decisions are inevitably damaging in the long term. The anxiety caused when individuals compare themselves to others and the stigma associated with lower social class appear to heighten this preference (SheenySkeffington \& Rea, 2017).

Being endowed with personality traits that suit certain job requirements, motivation factor, temperament and intellectual capabilities may encourage students to venture into certain careers. Some students realize their hidden potentials and choose jobs that are in congruence with such traits when they are young. Such students grow up knowing what they will do in life. Mcglynn, (2007) indicated that when such young people's immediate environment provides the necessary resources, they can really be the best they can be, because they go extra mile to reach their dream job. Opportunities and challenges associated with certain careers may serve as incentive or disincentive for students to choose some careers. For example, as some students are put off by challenges identified in certain careers, others see those challenges as avenues to explore in order to create a niche for themselves. 
Borchert (2002), found that the three important determinants of career choices were environmental factors, personality traits and opportunity. Borchert's (2002) study revealed that personality attribute is the most significant career choice factor.

Despite these revelation, Makinde (1990) indicated that many students choose careers without the needed guidance. Career guidance is the process of assisting young people to understand themselves and their world (Makinde, 1990). Several studies have indicated that students encounter numerous challenges when planning their occupational life (Olayinka, 1973). Students in Ghana are not exception. The education process therefore calls for career education as an important pathway to guiding students' choices. Morgan (2003) states that career education is the acquisition of knowledge, skills and attitudes through planned programmes of learning experiences which aimed at assisting students to make informed career choices for effective participation in future working life. Career education focuses on choice of subject and acquisition of skills for the performance of career roles (Abdukadir, 2002). Many students only realize that there is mismatch between what they learnt in school and industrial needs as they lack all the needed aptitude and preparations required to take up the few available jobs (Zunker, 2002). This render a significant number of them unemployed (Kampelmann \& Rycx, 2012).

Some unemployed blame their predicaments on uninformed choice of career meanwhile a lot of investments have gone into their education. In most cases the support might not be readily available to effect a change. Career decisions affect individuals either positively or negatively in their life time because the career path one chooses will make him/her move either forward or backward and sometimes be stagnant in terms of development during their working years. The situation of Senior High School Referred Graduates (SHSRGs) may be worse. A significant number of young people in Ghana leave SHS without the requisite qualifications. In most cases, some of them could not get good grades in some of the courses registered and others also are obliged to re-sit all the papers. The recurrence of these results deficiencies has escalated the unemployment problems of Ghanaians because not all the affected students decide to re-sit the referred papers. According to West African Examinations Council, (2017), a total of 58,351 candidates had F9 in various subjects representing 20.4 percent of the total number of candidates and 25.5 percent had between D7 and E8 in the 2017 West Africa Secondary School Certificate Examination (WASSCE) (West African Examinations Council, 2017).

There is an unanswered question about effective application of the acquired WASSCE results of the SHSRGs due to their low grades. In Ghana the cut-off point for admissions into tertiary institutions is C6. Certain programmes such as medicine and pharmacy require higher grades. Yet, many of them have F9, E8 and D7 and the number increases every year. Few of these disadvantage young people rewrite the referred papers and sail through at their first or second attempts. Consequently, it has been a ritual for many SHSRGs to resit every year because they are unable to make the grades required to pursue programmes in line with their career aspirations. Sometimes, their academic progression is delayed unduly thus, SHSRGs are generally baffled as to whether to forfeit their preconceived career decisions or seek for alternative occupational path (Wyness, McGuigan \& McNally, 2016).

Significant number of them are compelled to accept vulnerable employment making them live in sub-existing life. Studies on factors that determine vulnerability in the labour market conducted in selected low-income countries in Africa on what account for youths vulnerability more than other working groups found that labour force involvement rate in terms of high paid jobs are usually lower for young people in their exploratory stage (15years to 24 years) than all other age groups (Bhorat, Oosthuizen, Lilenstein, \&Thornton, 2016). The situation of those without WASSCE certificates is likely to be worse. Considering some targets of the United Nation's Sustainable Development Goals it seems the problems of SHSRGs is rather compounding as their predicaments heighten to pervasive levels. Critical assessment of the plight of SHSRGs gives an indication of obvious contravention with what SDGs is purported to achieve by 2030 (United Nations, 2015). There are factors such as personality traits, vocational interests, academic achievement, parents' socio-economic status and demands from mentors and extended family that may have different effects on educational aspirations and future career of school going students and referred ones alike. Some of the personalities such as teachers and parents who influence these graduates may themselves be ignorant about current trajectories in the world of work that ought to dominate career decision discussions.

In Ghana, the Cape Coast Metropolis is known for having good schools and considered to be one of the best educational centres. However, some schools in the metropolis are under resourced and such schools have been recording weak results in West Africa Secondary School Certificate Examinations (WASSCE). Recurrence of such weak results has aggravated unemployment situation in the metropolis as some of the students give up their pursuit of better certificates. Activities of remedial schools make SHSRGs situation glaring in the metropolis. This study aims at providing evidence that strengthens the SHSRGs literature by examining the differential developmental pathways of career choices and processes they consider as a way of engaging in sustainable 
employment. The study, therefore, looks at the career decision-making difficulties of these SHSRGs with a view of exploring how their choices have been influenced and challenged regarding their inability to get preferred tertiary institution. This is because literature does not particularly tackle this problem. As a way of filling the existing research gap with respect to various career determinants, this study was conducted to inform the career decisions of this segment of school leavers. The study sought to assess career decision-making difficulties encountered by Senior High School Referred graduates in the Cape Coast Metropolis. The following research question and hypothesis guided the study. How difficult is career decision-making for Senior High School referred graduates in the Cape Coast Metropolis? Study Hypothesis $\boldsymbol{H}_{\boldsymbol{o}}=$ The difficulty of SHSRGs in the Cape Coast Metropolis in career decision-making processes is not statistically significant in relation to factors (personal, environmental and situational) determining their career choices.

\subsection{THEORETICAL FRAMEWORK, CAREER SELECTION AND DETERMINANTS OF CAREER FAILURE}

\section{i. Theoretical Underpinnings}

The global community is currently confronted with employment challenges which consequently affect individuals of different cultures. In the midst of an array of work-related concerns, individuals have the quest to find meaning of life through work roles and societies have responsibilities to create job. Therefore, there are indications of diversity in cultures in terms of work roles. These impact on individuals either positively or negatively (Richardson, 1993). Osipow (1990) acknowledging the emerging nature of career development theory, assured researchers and practitioners that an incomplete theory is better than no theory. Theorists have acknowledged the value to be gained from attempting to provide a more integrative theoretical picture of career development (Borgen, 1991). This study was located within the Self Concept Theory of Career Development, Holland Theory of Vocational Types and the Decision Dynamics in Career Choices.

Self-concept theory of development was propounded by Donal Super (Super's career development theory) (Super, 1980). With an existence of voluminous literature on career choice and career development theories, Super's career theory is among the highly used worldwide and countries including the USA and Japan have applied it substantially. Super $(1980,1990)$ posit that career choice and development is a systematic stage of developing and implementing an individual's self-concept. Over time, self-concept changes and progresses as a result of experiences therefore, career development involves a whole lifespan of a person. It is inevitable for people to choose a career that reflects their environment and nurture with the premise that self-concept changes over time and grows because of experience (Super, 1990; Dokosi, 2014).

Donald Super recommended a progressive framework using elements of life stage for which an individual is expected to effectively manage the developmental task that is socially expected of a person in a chronological age range. The elements of life stages include growth, exploration, establishment, maintenance and disengagement (Super, 1990). Based on this, Super's theory divides a persons' working life into five stages. Stage one is termed growth that is age 4-14 years representing development of self-concept, attitudes, needs and general need of work. Stage two is exploration, age15-24years which is the "Trying out" through classes, work experience, hobbies, tentative choice and skills development. The stage three is establishment that is 25-44years. It is the early level skill building and stabilization through work experience. The stage four is called maintenance and it is age $45-$ 64years. That stage is noted for persistence in adjustment process with the aim of improving position. Stage five is the final stage and it is known as disengagement. It is the age of 65+ years and it is marked by reduced output and retirement. According to Herr (1997) and Savickas (1997, 2002, 2005), adolescent ought to satisfy the conditions which among others are pre-requisite for success in their career and social life. They include coping with vocational development task of crystallization that is an adolescents' skills, interest and values to study career goals that are in line with their understanding through a cognitive process (Herr, 1997; Savickas, 1997, 2001, 2005). Another condition is where the adolescent look for specifics in terms of choosing a career. This is where many factors come to play and the process is termed specification. Finally, Herr and Savickas suggest that a chosen career must be learnt and mastered through training, schooling and job position. This is referred to as implementation. For a young person to have an occupation he needs intensive training and to have a profession he needs intensive schooling (Herr et al., 2002, 2005). Patton (2002) used career maturity variable to indicate that an individual is able to satisfy the vocational development task needed at each developmental stage.

Another theory which underpins this study is Holland theory of vocation types. Holland focused on behavioural style or personality types otherwise called temperaments as the main influential factors to consider when choosing a career (Holland, Daiger, Power. 1980). These behavioural styles are the wealth embedded in every human being 
and they are at work always through an individual's lifespan. "If we refuse to take advantage of them, they will definitely take advantage of us and make us slaves instead of masters" (Tsipor 2014, p.12). This is described as structurally interactive. The theory spelt out the following themes; Occupational choice is expression of personality and not random; All those found in a particular work group, like teaching occupation have similar behavioural style; Members in each occupational group would organize resistance to situations and challenges in similar manner. The theory emphasises six personality types (Realistic, Investigative, Artistic, Social, Enterprising, and Conventional (RIASEC). Holland Theory of Vocational Types postulates that occupational achievement, stability and satisfaction depend on congruence between one's personality and job environment.

Decision Dynamics in Career Choice was propounded by Brousseau, Driver, Eneroth and Larsson (1993). They identified four decision dynamics in career and success. These dynamics are linear concept, expert concept, spiral concept and transitory or roamer concept. Linear concept is identified with people who think that moving up the corporate ladder is the only path to success. The motive for this category of people includes power and achievement. They are characterized with cost-efficiency, leadership skills and can manage logistics very well. They dwell on profit and do well to compete in order to ascend to the targeted apex of the organization's structure. Current research has proved that it is a difficult concept to career success. Ascending the organizational hierarchy provides limited positions into which to progress. Many who carry linear concept encounter frustrations (Driver, 2002). Until recently, employees could join an organization fully expecting to stay with it for the entire career. That has been the tradition of career perception of an upward movement in work role within a single organization (Baruch \& Budhwar, 2006).

Individuals with expert concept believe success is seen in being the best among peers. Students' whose parents have businesses, practice under them and aspires to follow the same career path have this type of concept. Such aspirations enhance entrepreneurship and sustainability of existing businesses. Alexander Robbins although believe in the expert concept yet he adviced that young people should separate their expectations from those of their parents otherwise they will not be on their own in deciding on their careers (Robbins, 2006). Expert people's aim is ensuring that they have job security so they seldom change job and therefore master in their job responsibility. They translate their technical competence reliability and commitment to job roles in order to ensure quality always.

People with spiral concept see success as being able to move from one position to related but often broader position. It is common these days to see engineers who practice in the practical fields shifting to managerial positions after further education and training. The subject of world conversions and conferences such as the World Education Forum, (WEF), Education For all (EFA) agenda (UNESCO, 2015) and Universal Declaration of Human Rights in 1948, (UN, 2006) have resulted in many people going to school globally. However, some scholars have argued that the growth of college attendance has resulted in changes in the world of work, specifically, as college attendance increases, graduates move from manufacturing and agricultural jobs toward technology, education, and healthcare positions (Goyette \& Mullen, 2006). Spiral oriented peoples believe in personal growth and creativity. They do not stay in a particular organization for their life-time, normally between seven (7) years to ten years is good for them. They are endowed with creativity and skills diversity. People's development has been mandated in addition to working in teams to achieve a set goal.

Individuals who believe in transitory or roamer concept sees success as being able to change jobs often. Transitory people are freedom loving. They treasure experiencing what happens in different work environment therefore they ensure that their stay in one field do not exceed five (5) years, normally between three (3) years to five (5) years (Driver, 2002). They are characterized with fast learning, project focus and manage social capital very well as they network with good contacts to enhance employability anytime they desire to change job. King's study on UK graduate's preference for career concluded that for employability, it is important for people to do variety of jobs in order to gain a range of experience (King, 2003). A caution from Collins suggests that the staggering array of jobs, rapid changes in the economy and the world of work have great potential of misleading people to make mistakes and that misery is likely to happen when people get into the wrong work (Collins, 2007).

\section{ii. Career Selection}

Career selection is one of the many important decision's students will make in determining future plans. This has long term effects on their lives. Good career decision is rewarding whilst unguided career decisions often times result in regrets. Herr, Cramer and Nile (2004) suggest that career decision of a person depends primarily on measured abilities, indicating that every individual should have a career goal. Currently, choice of career has been a challenge for many SHS students in Ghana. Career choice is therefore relevant decision that every individual ought to make irrespective of age and sex. Many learners aspire to have joyful life after studies; they also know 
that to be successful in life they have to endure numerous challenges. They may be aware of some of the hurdles ahead but in most cases situations thwart their career plans (Olamide \& Olawiye, 2013).

Students fail to factor in availability of jobs and their qualifications in career plans and rather maintain hopes of being employed immediately after completion of their studies. Coughlan argued that many students have a weak understanding of potential earnings and qualifications for different types of jobs that should guide and challenge them to persevere in studies since it is frustrating to catch up with missing qualifications when many years have elapse (Coughlan, 2013). Career choice is perceived as a major role among others in students' identity development which has two prong elements. They are exploration and commitment formation. Bureaucrats have proposed that young people have to undertake a psychological task for individuals to construct a stable and viable identity and thus have control over their own progress and negotiate their passage from adolescence to adulthood and the world of work ((Schwartz, Cote, \& Arnett, 2005; Cote \& Levine, 2002; Nurmi, Poole \& Segina, 1995). Cote et al., (2002) further stressed that young people can have control over their development by setting achievable future objectives, exploring deferent identity alternatives and committing to certain career path.

Involving individual students in what concerns them regarding career choice is referred to as commitment formation. The situation where students are confronted with several career objectives and have to consider the best out of these different possibilities is also called exploration according to Kunnen (2013). Career commitments are made in schools and in career domain. In order to study career choice as part of identity development, knowledge is required in working towards commitment formation. The task of students to identify who they are, and what are their goals (Schwartz, 2012), is closely depended on construction of individual's personal objectives that optimize these young students' ability to manage developmental challenges ahead of them (Battles, 1997; Salmela-Aro et al., 2012).

\section{iii. Determinants of Career Failure}

Dreams and aspirations of people's career differ and some people's career do not work for them as anticipated (Power, 2017). Power (2017) further indicated that no matter the precautionary measures put in place to ensure undisturbed career pathway there will always be an obstacle that may hinder the process. It is anticipated that the school system is a panacea to minimizing the unforeseen obstacles of individual's career pathway.

Today, many scholars from educational sector see education as basic Human Rights that should be accessible and affordable to everybody (Opolot \& Enon, 1990). However, not all schools are resourced to meet standards that can prepare young people to be employable. Employability implies characters that may make job seekers attractive to potential employers (Bridgstock, 2009). Coexistence and persistence of increasing divergence of these two situations in the education system (well-endowed and less endowed) make some schools produce graduates with strong grades and others at risk of recording weak results. Failure for a student to perform creditably in any of the subjects will reduce academic aspirations of the student and the parents. Under resourced schools lack laboratories, qualified teachers and infrastructure to boost the teaching and learning process. Students from such schools often perform poorly, spend several years to better weak grades and at times truncate their education for no progress in previous efforts. Studies using different approaches have proven that learners with diverse features may need differing levels of resource to meet performance goals (Duncombe \& Yinger, 2000; Chambers, et al., 2004, Picus, Odden \& Fermanich, 2003). These obstacles derail individual's career pathway.

In Ghana, people believe that under achieving students who seem highly at risk of career failure be enrolled in Technical and Vocational Education Training (TVET) to acquire a skill. However, Holland's six personality types suggest that those who excel in TVET are individuals with Realistic traits (people who like to work with tools, machines and value practical things that can be seen and touched, such as mechanical, electrical, construction, farming and others). Holland, et al. (1980) indicated, one out of six who skew towards TVET line. Designers and implementers of TVET argued that TVET is inherent in the achievement of Education 2030 which mandates international community to "Ensure inclusive and equitable quality education and promote lifelong learning opportunities for all” (UNESCO, 2015). Holland et al. (1980) explained that in any situation people with investigative, social, artistic, enterprising and conventional personalities constitute the majority in the labour market. Students who underachieve may not have a trait in realistic and therefore not fit for practical oriented careers and vice versa (Holland, et al.1980).

A study in Nigeria by May, Arogundadade, Ekundayo (2007) found that Technical and Vocational education are neglected in terms of funding, personnel, modern equipment and staff motivation which has affected enrolment across the country and as a result rubbing the country of development. Another research conducted in Nigeria indicated that people's interest in Technical and Vocational education seems to reduce contributing to dwindling of skilled personnel to feed the labour market (Momoh, 2012). According to Wisegeek (2013), educational system should take care of all sorts of people by considering strengths, weakness as well as varying aspirations. Wisegeek 
(2013) explained that vocational training is education and training with much emphasis on practical skills that are required in practical industries whilst technical training, though similar, focuses on technology development in computers and digital information. Perceptions and psyche of many Africans seems to suppress this sustainable development agenda of TVET as many students and parents have preference for general education instead of TVET. Studies by scholars have proven that there is prestige and more money in investigative, enterprising, social and arts profession than practical oriented discipline (Holland, et al. 1980). General education prepares learners for higher level of education; some of the courses in this context are academic and theoretical (UNESCO, 2015).

Students also have the responsibility to direct their own career (Meijers \& Warderkker, 2002). Becoming selfdirecting demands acquisition of knowledge and specific competencies which are pre-condition for career success (Savickas, 2001). Such competencies are referred to as career competencies that steer the development of a person's career in a particular direction (Kuijpers, Schyns \& Scheerens, 2006). Various views have been expressed by scholars on career issues including career selection and determinants of career failure however much has not been discussed on career decision-making difficulties of Senior High School Referred Graduates in the Cape Coast Metropolis hence this study was conducted to fill that gap.

\section{METHODOLOGY}

Exploratory design and mixed method approach (quantitative and qualitative) were used for the study. In this context, the qualitative method was used as a complement to that of the quantitative and in the vice versa (De Tona, 2006). Pragmatism paradigm was adopted depicting a philosophical framework that underpinned the study. It suggests that the popular approach to making an investigation is that of blending data gathering procedures and analysis within the study process (Creswell \& Plano-Clark, 2007). Pragmaticism proffers wide-ranging and indepth comprehension of occurrence under investigation and abhors the idea of absolute invariable truth, instead emphasizing that truth is what works. Thus, believe in mixing qualitative and quantitative methods when undertaking a research such as finding a solution to decision-making difficulties of SHSRGs.

The research was conducted in the Cape Coast Metropolis where the administrative capital of the Central Region of Ghana is located. The metropolis comprises of two sub-metropolitan areas, Cape Coast North and Cape Coast South. It shares a common boundary with Komenda/Edina/Eguafo/Abriem Municipal on the west, Abura Asebu/Asebu/Kwamankese on the east and Twifo/Heman/Lower Denkyira on the north. However, the southern part is the Gulf of Guinea. Many visitors across the globe visit Cape Coast Castle because of the castle, schools and traditional edifices in the area. The economic activities in the metropolis consist of fishing, craft, trade, teaching and government administrative work. According to the 2010 population and housing census, the total population is 169,894 which disaggregates into 82,810 being males and 87,084 females. Out of this population, those employed in the service sector alone is $32.5 \%$ and $13.2 \%$ being professionals whilst $30.7 \%$ is shared among other occupational fields (GSS, 2010). Currently, Senior High Schools in the area stands at fourteen (14). Some of the schools in the area are among the popular and good ones in Ghana. University of Cape Coast, Cape Coast Technical University and Our Lady of Grace (OLA) College of Education are the common tertiary institutions in the area whereas Wesley Girls, Holy Child, Adisadel College, Mfantsepim and St. Augustine College are among the best secondly schools in the Metropolis. Remedial schools (Royal Rich College, Pass-well Remedial School and several others) abound and most of them are run in public basic schools. The percentage of the population that are in primary schools constitute $27 \%$, JHS $-13.1 \%$, SHS- $11.4 \%$ and tertiary-34.4\% (GSS, 2010). 


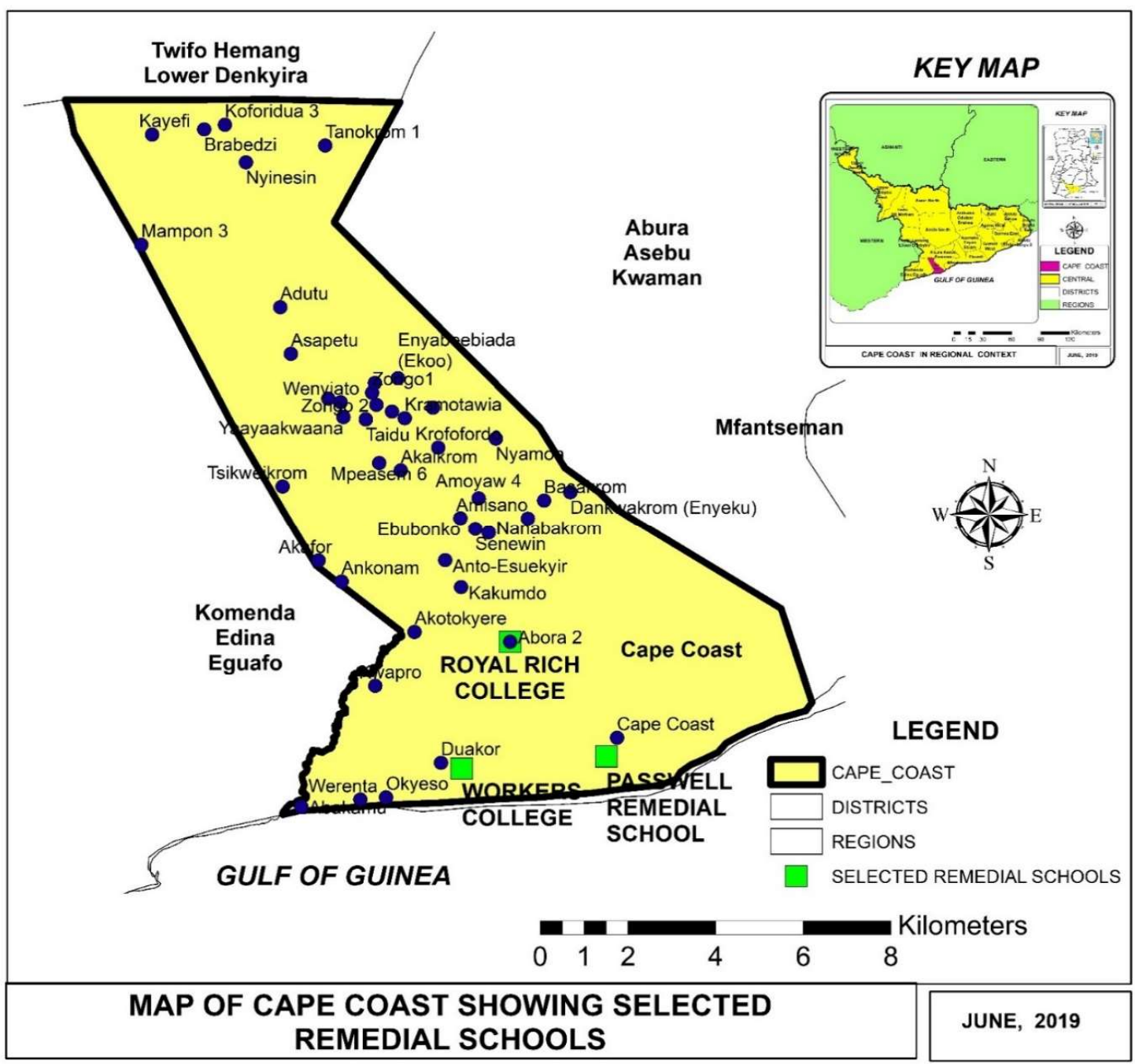

Figure 3.1: Map of Cape Coast Metropolis

The population of the study comprised of Senior High School referred graduates in the Cape Coast Metropolis, their parents, teachers and the education directors. The target population is the Senior High School referred graduates in the Cape Coast Metropolis who completed school from 2013-2018. The total target population is estimated to be approximately 9000 referred graduates that are in both remedial schools and those that are at home and are not attending any remedial school. A sample of 150 SHSRGs were selected from three (3) remedial schools in the Cape Coast Metropolis whilst two hundred and ten (210) SHSRGs who were not in remedial school were selected from the accessible population of 7000. The sample size of the referred graduates in remedial schools was

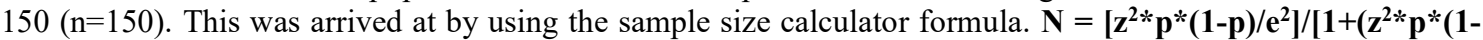
$\left.\mathbf{p} /\left(\mathbf{e}^{2 *} \mathbf{N}\right)\right]$ Where: $\mathrm{N}=$ Population size $(480) \mathrm{p}=$ Population proportion $(90 \%) \mathrm{e}=$ Margin of error $(4 \%) \mathrm{z}=1.96$ for the confidence level of $95 \%$.

Stratified and random sampling techniques were adopted to select a total of three hundred and sixty (360) SHSRGs. Eight (8) of the 360 referred graduates who answered the questionnaires were conveniently chosen for interview. Purposive, convenience and snowball sampling techniques were also used to select six (6) parents, three (3) remedial school teachers and one (1) director of Ghana Education Service (GES) for the study. Data collection was done using questionnaires and semi structured interview guide. These constituted the primary data and offered functional as well as essential data (Andrews, Nonnecke \& Preece, 2003; Andrews et al, 2003) from the accessible SHSRGs, their parents, teachers and GES Director in the study area. The research question was on career decisionmaking difficulties of SHSRGs with emphasis on career selection, determinants of career failure, working conditions and career requirement. The quantitative data relied mainly on descriptive statistics (standard deviation, 
frequency, mean percentage and frequency) in their analyses. Inferential statistics including t-test, correlation and regression were also employed for the analyses of the research hypothesis whilst thematic approach was used to analyse the qualitative data.

\section{FINDINGS AND DISCUSSIONS}

\section{Demographic Characteristics of SHS Referred Graduates}

The data on the demographic characteristics of the respondents show that 155 (43.3\%) of the Senior High School referred graduates who participated in the study were males whilst $203(56.7 \%)$ respondents were females. The results on the gender variable could imply that more females are referred in SHS than their male counterparts. The data from the study further reveal that the maximum age accordingly was 26 years and above $(n=34,9.6 \%)$ and the minimum age was below 16 years $(n=1,0.3 \%)$. It is also worth noting that majority of the participants were between the ages of 16 and 25 years. While 164 participants (46.3\%) were within the 16 to 20year age range, 155 $(43.8 \%)$ were within the 21 to $25 y e a r$ age range. Based on Super's theory, most of the participants were within the exploratory stage which is the "Trying out" through classes, work experience, tentative choice and skills development. Comparing this age ranges with the recommended age one should be in the tertiary (19 years as suggested by Ministry of Education, 2013), it can be observed that these referred graduates may receive their tertiary education later than expected which would hinder the number of years they may spend on the selected careers.

\section{Career decision-making difficulties of SHSRGs in the Cape Coast Metropolis}

The results on career decision-making difficulties indicated that SHSRGs did not face much difficulty in their future career selection. The referred graduates were required to rate how difficult it was for them to make decision in relation to their career on a five-point Likert scales ranging from strongly agree to strongly disagree. However, the five-point scale was collapsed into three-point Likert scale thus; "strongly agree" and "agree" become "agree", whilst "strongly disagree" and "disagree" become "disagree" and "undecided".

A cursory observation of the data presented revealed that majority of the SHSRGs did not face much difficulty in making decision in relation to their future career. For example, the data show that $263(74.3 \%)$ of the participants indicated that they had considered the field to major in or the occupation to choose in the near future. When the respondents were asked whether they did not have the motivation to make the decision in relation to selecting their future career, majority disagreed $(n=209,59.0 \%)$. Again, about 76.6\% $(n=271)$ of the SHSRGs asserted that they disagreed to the item on whether work was not the most important thing in their life and therefore the issue of choosing a career was of concern to them. In the same regard, majority of the respondents indicated their disagreement with the assertion that they do not have to choose a career, as at the time they were in the house, because time and chance would lead them to the "right" career choice $(n=267,75.9 \%)$. The results moreover suggest that $189(53.8 \%)$ of the SHSRGs agreed that they usually need confirmation and support for their decisions about their career choice from a professional person or somebody they trust.

An examination of the data presented indicates that $72.2 \%(n=255)$ of the referred graduates disagreed to the item which suggested that they find it difficult to make a career decision because people who are important to them do not agree with their career options. The data show that $71.8 \%$ (254) of the respondents disagreed that they find it difficult to make a career decision because of inadequate knowledge on their abilities and/or personality traits. This implies that some of them considered personality traits in their career decision-making processes. This is in line with Holland's theory of vocation types which emphasised personality traits as the main influential factors to consider when choosing a career (Holland, Daiger, Power. 1980). An overwhelming majority of the respondents claimed that they were expecting to fulfill all their aspirations through the career they would choose $(n=288$, $81.4 \%$ ). The SHSRGs also disagree to the statement "I find it difficult to make a career decision because I do not know steps I have to take" ( $n=238,68.2 \%)$ suggesting that it was easy for them to make career decisions. Information presented further revealed that most of the respondents did not find it difficult to make a career decision because they did know what factors to take into consideration in making such decisions $(n=241,69.5 \%)$. It was also established that most of the participants did not find it difficult to make a career decision because they did know how to combine the information they had about themselves with that of different careers opportunities $(n=219,61.7 \%)$. The results as presented reveal that the SHSRGs were of the opinion that they did not find it difficult to make a career decision because of their interest in certain occupations $(n=261,73.9 \%)$. And finally, the respondents disagreed to the suggestion that they found it difficult to make a career decision because they were focusing on their referred papers $(n=226,63.5 \%)$. The responses of the participants are presented in Table 4.1. 
Table 4.1. SHS Referred Graduates' Difficulty in Career Decision-Making

\begin{tabular}{|c|c|c|c|c|c|}
\hline No & Statement & D (\%) & U (\%) & A (\%) & $M(S D)$ \\
\hline 1 & $\begin{array}{l}\text { I have considered what field I would like to major in } \\
\text { or what occupation I would like to choose }\end{array}$ & $50(14.1)$ & $41(11.6)$ & $263(74.3)$ & $2.6(0.7)$ \\
\hline 2 & $\begin{array}{l}\text { I know that I have to choose a career, but I don't have } \\
\text { the motivation to make the decision now }\end{array}$ & $209(59.0)$ & $40(11.3)$ & $105(29.7)$ & $1.7(0.8)$ \\
\hline 3 & $\begin{array}{l}\text { Work is not the most important thing in my life now } \\
\text { and therefore the issue of choosing a career doesn't } \\
\text { worry me much }\end{array}$ & $271(76.6)$ & $36(10.2)$ & $47(13.3)$ & $1.4(0.7)$ \\
\hline 4 & $\begin{array}{l}\text { I believe that I do not have to choose a career now } \\
\text { because time will lead me to the "right" career choice }\end{array}$ & $267(75.9)$ & $35(9.9)$ & $50(14.2)$ & $1.4(0.7)$ \\
\hline 5 & $\begin{array}{l}\text { I usually feel that I need confirmation and support for } \\
\text { my decisions from a professional person or } \\
\text { somebody else I trust. }\end{array}$ & $115(32.8)$ & $47(13.4)$ & $189(53.8)$ & $2.2(0.9)$ \\
\hline 6 & $\begin{array}{l}\text { I find it difficult to make a career decision because } \\
\text { people who are important to me do not agree with the } \\
\text { career options I am considering }\end{array}$ & $255(72.2)$ & $44(12.5)$ & $54(15.3)$ & $1.4(0.7)$ \\
\hline 7 & $\begin{array}{l}\text { I find it difficult to make a career decision because I } \\
\text { do not know what my abilities and/or personality } \\
\text { traits will be like in the future. }\end{array}$ & $254(71.8)$ & $48(13.6)$ & $52(14.7)$ & $1.4(0.7)$ \\
\hline 8 & $\begin{array}{l}\text { I expect that through the career I choose I will fulfill } \\
\text { all my aspirations }\end{array}$ & $30(8.5)$ & $36(10.2)$ & $288(81.4)$ & $2.7(0.6)$ \\
\hline 9 & $\begin{array}{l}\text { I find it difficult to make a career decision because I } \\
\text { do not know what steps I have to take. }\end{array}$ & $238(68.2)$ & $43(12.3)$ & $68(19.5)$ & $1.5(0.8)$ \\
\hline 10 & $\begin{array}{l}\text { I find it difficult to make a career decision because I } \\
\text { do not know what factors to take into consideration }\end{array}$ & $241(69.5)$ & $37(10.7)$ & 69(19.9) & $1.5(0.8)$ \\
\hline 11 & $\begin{array}{l}\text { I find it difficult to make a career decision because I } \\
\text { don't know how to combine the information I have } \\
\text { about myself with the information I have about the } \\
\text { different careers. }\end{array}$ & $219(61.7)$ & $52(14.6)$ & $84(23.7)$ & $1.6(0.8)$ \\
\hline 12 & $\begin{array}{l}\text { I find it difficult to make a career decision because I } \\
\text { still do not know which occupations interest me. }\end{array}$ & 261(73.9) & $33(9.3)$ & $59(16.7)$ & $1.4(0.7)$ \\
\hline 13 & $\begin{array}{l}\text { I find it difficult to make a career decision because I } \\
\text { am focusing on my referred papers now }\end{array}$ & $226(63.5)$ & $41(11.5)$ & $89(25.0)$ & $1.6(0.8)$ \\
\hline
\end{tabular}

Key: $\mathbf{D}=$ Disagree, $\mathbf{U}=$ Undecided, $\mathbf{A}=$ Agree, $(\mathbf{\%})=$ Percentage, $\boldsymbol{M}=$ Mean, $\boldsymbol{S D}=$ Std. Deviation.

Source: Field Survey, December, 2019.

Despite the responses given by the SHSRGs in the quantitative data suggesting that they did not have difficulty making career decisions, the qualitative data revealed otherwise. While seven out of the sixteen referred graduates who participated in the interview did have difficulty making career decisions, four of them encountered some difficulties because they were torn between two careers. Views of the Participants of the interviews are presented in the following themes.

Difficulties Associated with Career Decision-Making of SHSRGs

The interview data revealed that SHSRGs had challenges with career decision-making because some of them had two careers and were confused on the one to choose whilst others had career decision difficulties as a result of financial demands associated with their dream career. The type of career a person chooses will determine whether he or she will move upwards, downwards or stay stagnant on his or her career pathway. For this reason, some people are confronted with challenges when choosing a career. As part of the study, participants were asked to indicate whether they encountered challenges making career decisions.

Participant A, aged 19 was of the view that she had two options and stated: I have two careers to choose from; nursing and teaching. I am still figuring out the one which fits me well. I had a lot of difficulties choosing my career. When I was growing up, I wanted to do something else, but later on I considered my potentials and my strength and saw that my area is to become either a nurse or a teacher. Sometimes, I become confuse... 
This may imply that Participant A did not take career counselling seriously in her previous school. Many students do not pay much attention to unexaminable programmes and often absent themselves when they become aware of counsellors' appointment to engage students on career issues. Such students lack basic information about their chosen fields and normally become indecisive when it comes to career commitment. This finding supports observation of Couglan (2013) that many students have a weak understanding of potential earnings and qualifications for different types of jobs that should guide and challenge them to persevere in studies since it is frustrating to catch up with missing qualifications when many years have elapse.

Participant $\mathrm{C}$ seems not to have any challenge in selecting her career. She shared her experience and stated: "I did not have difficulty in choosing the career. Nobody influenced me; we were advised on how to choose our courses. It is an advice; it is based on your own decision. You can advise me that when I go here things won 't be bad. It's up to me to finalize my decision".

Some of the referred graduates were still considering the careers they should choose while others were certain about careers they can pursue. Such people indicated that they had considered their personality traits, their strengths and weaknesses and were sure of what they can do in future. This is in line with Holland's Theory of Vocational Types which focused on behavioural style or personality types as major influential factors to consider when choosing a career. There were some SHSRGs who indicated that they were having difficulty settling on their dream career because of financial challenges but not that they do not know the factors they have to consider when choosing a career.

Participants E stated: "Financial constrains has been the main set back in achieving my career. I have to forgo the idea of becoming a journalist and trade in cosmetics because of financial problems. Initially I wanted to become a journalist but as at now I don't think about it anymore. I have resolved to go into cosmetic business. It is my situation that influenced me. I am only considering my second option. Even that...or look for alternative career. I don't have money to start it now".

From these submissions it was clear that some of the SHSRGs were having challenges with career decisionmaking not as a result of inadequate career knowledge but financial demands associated with the careers they want to pursue. Unlike Participants E, A and C, Participant B was rather thinking about the money she will get from the career as suggested by her uncle. Mcglynn (2007) was of the view that most students consider only the economic aspect of their future career - they are more concern with the amount of money they can earn leading few of them being able to pursue their dreams.

\section{Parents' views on Difficulties Associated with Career Decision-making of SHSRGs in the Cape Coast} Metropolis

The parents talked about financial challenges posing barriers to their wards interest in certain careers and shared their views on career decision making difficulties.

Participant O noted: My daughter's father died before she was born hence her name (Antobam). The man I am staying with did not take good care of her. It was somebody else who supported me to care for her secondary education. When she completed my finances were bad. That's why she could not continue to rewrite her weak papers. We don't even know the work she can do best in future, only God knows how her working life will be.

Participant O's daughter was from poor socioeconomic background and because she did not make it with opportunity offered by the philanthropist, she was likely to end her education at that level to continue the vicious circle of poverty in the family. However, if she takes a prudent decision and equip herself with skill training, she can be successful. Poor socioeconomic background may prevent individuals from pursuing their dream career. Power (2017) noted that dreams and aspirations of people's career do not work for them as anticipated.

\section{Entrepreneurship as Career Decision Option of SHSRGs in the Cape Coast Metropolis}

Some of the participants indicated that they were interested in establishing their own businesses whilst others chose entrepreneurship as option in situations where they encountered difficulties in career decisions. For some time now, it had become obvious that the government alone cannot provide jobs for the youths hence they are being encouraged to create their own jobs. 
Participant D stated: Right from secondary school I had in mind of establishing my own company. I visit the social media a lot to get more knowledge in the company l planned to establish. I have interest in fashion; I want to do something with my hand and be a boss.

On the contrary, some of the participants chose to set up their own businesses when they were unable to pursue their dream career. These views expressed by the participants were in line with the Self Concept Theory of Career Development. Some of the SHSRGs' self-concept, over time have changed as a result of their experiences (Super, $1980 ; 1990)$. For example, Participant E shared her experience and stated:

The way things have become I don't think about becoming a journalist anymore. Upon several discussions with people, I want to stick to the cosmetic business. I'm 100\% sure of becoming an entrepreneur.

Participant E expressed much zeal in sticking to her career alternative. She had already made career commitment to become a business woman and vowed not to make a mistake in her decision. Her decision is in consonant with what Collins suggested that, the staggering array of job, rapid changes in the economy and the world of work have great potential to making mistakes and the misery that is likely to happen when people get into the wrong work (Collins, 2007).

The Educational Director talked about entrepreneurship as one of the programmes put in place to help SHSRGs in the Metropolis. Participant R stated:

The programmes I have put in place to help referred graduates in my jurisdiction is entrepreneurship. It is meant to equip the students. At the end of the day, after their senior high school, if they don't want to continue with their academic work then they would then establish using the training they got to be self-employed. So, the introduction of entrepreneurship in our school system is one of our interventions.

Participant $\mathrm{R}$ had made provision by inviting competent people to educate students in schools under his jurisdiction on entrepreneurship in addition to general education in order to offer several career alternatives to students. This may reduce the rate of vulnerability among SHSRGs who have to spend some time at home to work on remediation or give up to formal education. The finding relates to a suggestion offered by Sidney et, al. (1971) on career education that it is a blending of general education, college education and vocational education into an entirely new curriculum permeating the entire spectrum of youngster's education.

\section{Views on Some of the Difficulties Encountered When SHSRGs are Engaged in Career Selection}

As part of the study, teachers shared their experiences on the difficulties encountered when they engaged students in discussion on career decision-making and career selection and noted that parents normally dictate careers to their children frustrating their efforts. Teachers were expected to offer career education and to guide students in their career selection because they were close to them to identify their personality traits, potentials, talent, strengths and weaknesses. Moreover, students normally confide in them when it comes to issues concerning their future career. Teachers were experienced and per their work sought information on so many topics and therefore knowledgeable in job related issues. They were trained to offer career education and career guidance to students yet parents oppose their suggestions. Particularly, in situations where parents think their children are adamant, they should support them and make it clear to the children that they are responsible for the consequences of their decisions.

Participant M stated: "Sometimes a child may have two careers in mind and he is challenged to choose one, in such a situation you look at it and advice the child which one to select. There has always been some degree of friction anytime I dialogue with students about career selection”.

On the part of Participant M, he was concerned about how some programmes made students versatile to pursue various careers while others set limitations for students. He noted: The difficulty is that those with general arts as specialization cannot change to become medical doctors but it will not be difficult for science students to become journalists especially in Ghana. This draws the attention to the need to reconsider Ghana's educational system in order to offer more career opportunities to students.

The Ghana Education Service Director also expressed his sentiment on challenges associated with recruitment of guidance and counselling coordinators in the Metropolis.

Participant R stated: "The challenge is that, this office has only one guidance and counselling coordinator for the metropolis. We rely on teachers to help them in career selection although some teachers do not have career background... 
This finding supports the observation of Onumah (1992) that guidance and counselling coordinators were few in almost all educational levels. The researchers were interested in hearing the views of parents on the difficulties their wards encounter during career selection and made enquiries from them to express their opinions on the issue.

Participant P said: "My son did not have serious challenges when selecting his career. I contacted one of the JHS teachers, and he told me that if he wants to be a teacher then he has to do general arts. I consulted that JHS teacher because I had close relationship with him”.

Many SHSRGs sought career information on their own apart from those received in schools. Participant P stressed that when his son identified his dream career, he consulted the teacher for in-depth knowledge on that career. He went to the appropriate person for guidance and used the information gathered to support his son's decision which is a good thing parents should adopt. When parents support their children but are not manipulative, the child will approach them when advice is needed. This finding supports Maze (2000) who said, parents of young people would like to have information about job opportunities such as military, nursing, and teaching.

Participant O said: When I realized that I cannot take her to remedial school to pursue her nursing, I convinced her to join me in my kenkey business but she refused. She wasn't prepared to hunt for bamboo and plantain leaves. She was absorbed as a teacher in a preparatory school in this village even though the salary is unattractive. I am finding it difficult to convince her. She has now giving birth and the man has not been caring for them.

Some parents lacked career knowledge that could be used as a guide to counsel their children and do not seek for expert's advice. Their children who are SHSRGs normally end up being victims of circumstances. They become more vulnerable when they fall in the hands of people who influence them negatively.

\section{Testing of Hypothesis}

$\boldsymbol{H o}=$ The difficulty of SHSRGs in the Cape Coast Metropolis in career decision-making processes is not statistically significant in relation to factors (personal, environmental and situational) determining their career choices.

To address the research hypothesis, a bivariate correlational analysis using Pearson product-moment correlation was conducted on the data set (career decision-making difficulty and career choice determinate). Preliminary analysis was conducted to ensure no violation of the assumptions underlining Pearson product-moment correlational analysis. The first assumption considered was scale of measurement. According to Field (2009), Pearson's correlation requires only that data are measured on an interval or ratio scale for it to be an accurate measure of the linear relationship between two variables. This assumption was met as all factors were continuous variable and measured on scale (interval or ratio scale). Another assumption that was considered was normality of the distribution; this assumption was met as the distribution of the dependent score was approximately normal with a mean of 3.71 and a standard deviation of 0.65 . Skewness and Kurtosis values of -0.58 and 0.66 respectively show that the distribution of the scores are approximately symmetrical and matches the Gaussian distribution. Assumption of linearity between career decision-making difficulty and factors determining their career choice was assessed using matrix scatter plot. This showed some linear relationship between the factors. These results showed that Pearson product-moment correlation assumptions were tenable. Table 4.2 shows descriptive statistics (mean and standard deviation) of the variables used in the bi-variate analysis. The data presented shows that Personal Factor had a mean score of 17.2 (2.5), Family Factor attracted a mean value of 17.3 (3.2), Situational Factor $(M=17.6, S D=3.1)$, and finally Career Decision-Making Difficulty attracted a mean and standard deviation scores of 35.5 (5.4). The bi-variate analysis results as shown in Table 4.2 indicate that there was both positive and negative correlation between career choice determinate (Personal Factor, Family Factor and Situational Factor) and Career Decision-Making Difficulty.

It is indicated in Table 4.2 that there was a non-significant weak positive correlation between Personal Factor and Career Decision-Making Difficulty $(r=-0.094, n=295, p>0.05)$. Furthermore, there was a significant positive correlation between Family Factor and Career Decision-Making Difficulty $(r=0.257, n=302, p<0.01)$. The magnitude of the relationship between the means of these two variables was small $\left(R^{2}=0.066\right)$. Thus, when the coefficient of determinate is expressed as percentage, it shows that $6.6 \%$ of the variance in Career DecisionMaking Difficulty is explained by Family Factor. Finally, there was a positive correlation between Situational Factor and Career Decision-Making Difficulty $(r=0.306, n=308, p<0.01)$. The coefficient of determination $\left(R^{2}\right)=0.094$. It therefore suggests that Situational Factor helps to explain about $9.4 \%$ of the variance in Career 
Decision-Making Difficulty. Direct conclusions about causality from a correlation based on the correlation coefficient of $(R)$ value cannot be made (Field, 2009).

The results are presented in the correlational matrix Table 4.2.

Table 4.2: Summary of inter-correlation, mean and standard deviation matrix

\begin{tabular}{|c|c|c|c|c|c|c|}
\hline Sub-scale & 1 & 2 & 3 & 4 & $M$ & $S D$ \\
\hline 1 Career Decision-Making Difficulty & 1 & - & - & - & 35.5 & 5.4 \\
\hline 2 Personal Factors & 0.09 & 1 & - & - & 17.2 & 2.5 \\
\hline 3 Family Factor & $0.25^{* *}$ & $0.30 * *$ & 1 & - & 17.3 & 3.2 \\
\hline 4 Situational Factor & $0.30 * *$ & $0.30 * *$ & 0.70 & 1 & 17.6 & 3.1 \\
\hline
\end{tabular}

The findings on the research hypothesis revealed that family and situational factors were among the major factors which had associations with career decision-making difficulty among Senior High School referred graduates in the Cape Coast Metropolis. There have been certain factors that have been identified as contributing to career decision-making difficulty among young people in literature. According to established literature, parents and siblings (mostly fathers and elder siblings), environmental and educational level highly correlate with career maturity and career decision-making. Literature further states that family members may sometimes have irrational expectations about the career decision making process of the young adult (Gati, Krausz, \& Osipow, 1996). These irrational beliefs might impact the kind of decisions that individuals make in negative ways. In the same regard Punch, Creed and Hyde (2006) are of the view that ethnic and gender discrimination, financial problems, family attitudes, perceived lack of ability and lack of educational opportunities have also been cited as acting as barriers to career decision-making. As stated by Crosby (2005) individuals sometimes tend to make assumptions about an occupation's environmental requirements, employment prospects and circumstantial (situational) variables therefore making decisions on inadequate and often misleading information.

\section{CONCLUSIONS AND RECOMMENDATIONS}

Financial problems constituted a major challenge to the attainment of career goals of SHSRGs in the Cape Coast Metropolis. Financial challenges derailed SHSRGs career plans. Such challenges brought career decision difficulties to them. Some of the SHSRGs were unable to meet financial demands of their chosen careers and this prevented them from completing their programmes successfully. Most of them had financial difficulties and needed some form of financial assistance and therefore require pragmatic policy to help them. The graduates were motivated and eager to choose their dream careers. They relied on professionals and people they trusted such as their teachers, counsellors and parents for confirmation and support. However, some of these stakeholdersimposed careers on these referred graduates. This situation further worsened the plight of referred graduates posing career decision-making difficulties.

Senior High School referred graduates experience difficulties pursuing their careers due to their weak result. Some of these referred graduates did not pass one or two subjects yet they were not able the further their education or pursue their dream career. Various educational and professional institutions in Ghana consider academic performance for placement and training and those without good academic performance are normally denied the opportunity. This has made SHSRGs vulnerable and prey of some people in society as they tend to these people for support to enable them gain admission to further their education or career. There is therefore the need to review the educational system to prepare students well for appropriate placement irrespective of their results and provide more avenues for such graduates.

It was therefore, recommended that SHSRGs in the Cape Coast Metropolis whose predicaments hinged on their weak results should rather exercise self-control and persevere in their next re-sit preparation so that investments made would merit the output. Government policies on TVET and National Entrepreneurship and Innovation Programme (NEIP) must be embraced by SHSRGs in the Cape Coast Metropolis. A combination of TVET (occupation-specific skills) and entrepreneurship skills is the perfect path to increase career options of SHSRGs thereby reducing unemployment and opening job (UNESCO, 2015). SHSRGs in the Cape Coast Metropolis should know that they are individuals with unique personalities and different career aspirations. They should therefore make career choices based on appropriate guidance and counselling received from experts in units established in 
various institutions across the metropolis. They should resist imposition of careers by people who divert their focus. This can minimize frictions between SHSRGs and parents who wished their wards pursue a particular career. SHSRGs in the Cape Coast Metropolis should accept non-collegiate education such as excursions and embrace work surveillance. This will sharpen their understanding about what industry expect from them, connect them to the realities in some working environment and the specific occupational area that motivate their employees. This will enable them to make informed decisions.

\section{REFERENCES}

Abdukadir, B. B. (2002). Issues in Nigeria educational system. Journal of Education Studies, Calabar, 7(3), 1517.

Andrews, D., Nonnecke, B., \& Preece (2003). Electronic survey methodology: A case study in researching hardto involve internet users. International Journal of Human Computer and interaction, 16(2), 185-210.

Battles, P. B. (1997). On the incomplete architecture of human ontogeny: process and Bulleting, 120, 338-375.

content. Psychological

Baruch, Y., \& Budhwar, P. S. (2006). A Comparative study of career practice for managing staff in Britain and India. International Business Review, 15, 84-101.

Bhorat, H., Oosthuizen, M., Lilenstein, K. \& Thornton, A. (2016). Vulnerability in employment: Evidence from South Africa. DPRU Working Paper 201604. Development Policy Research Unit.

Borchert, M. (2002). Career choice factors of high school students. Retrieved from http://www2.uwstout.edu/content/lib/thesis/2002/2002borchertm.pdf

Borgen, F. (1991). Megatrends and milestones in vocational behaviour: A 20-year counselling psychology retrospective. Journal of Vocational Behaviour, 39, $\quad$ 263-290.

Bridgstock, R. (2009). The graduates attribute we've overlooked: enhancing graduates employability through career management skills. Higher Education and Development 28 (1), 31-44.

Brousseau, K., Driver, M., Eneroth, K., \& Larsson, R. (1993). Career pandemonium: Realigning organization and individuals. Academy of management executive, 10 (4), 52-66.

Chambers, J. G., Parrish, Thomas, B., Levin, Jesse D., Smith, James, R., Guthrie, James, W., Seder, Rich, C., \&Taylor, L. (2004). The New York adequacy study: Determining the cost of providing all children in New York an adequate education. New York: American institute

Collins, H. (Ed.) (2007). Case studies in expertise and experience. History and Philosophy of Science, $38,4$.

Cote, J., \& Levine, C. G. (2002). Identity formation, agency and culture. London: Psychology Press.

Coughlan, S. (2013). Teenagers' mismatched job ambitions. Journal of Vocational Behaviour, 70, 501-524.

Creswell, J. W., \& Plano-Clark, V. L. (2007). Designing and conducting mixed methods research. Thousand Oaks, CA: Sage.

Crosby, O. (2005). Career myths and how to debunk them. Occupational Outlook Quarterly, 202, 691-5716. 
De Tona C, (2006). But what is interesting is the story of why and how migration happened. Retrieved from http://www,qualitative.net/fqs-texte/3-06-3-13-e.htm

Dokosi, E. D. (2014). Investigating the factors influencing career preference amongst prospective and recent graduates in Ghana. Accra: Ashesi University College.

Driver, M. J. (2002). Career concept and organizational change. In C. B, Derr, (Ed), Work, Family and Career (pp, 5-41.) New York: Preager.

Duncombe, W., \& Yinger, J. (2000). Financing higher student performance standards: The York State. Economics of education Review, 19, 363-386.

cases of New

Field, A. (2009) Discovering statistics using SPSS. (3rd Ed). London: Sage Publications Ltd.

Gati, I., Krausz, M., \& Osipow, S. H. (1996). A taxonomy of difficulties in career decision-making. Journal of Counseling Psychology, 43, 510-526.

Goyette, K., \& Mullen, A. L. (2006). Who studies the arts and sciences? Social background and the choice and consequences of undergraduate field of study, The Journal of Higher Education, 77(3) 497- 538.

Herr, E. L. (1997). Super's life-span, life-space approach and its outlook for refinement. The Career Development Quarterly, 45, 238-245.

Herr, E. L. (2002). School reform and perspectives on the role of school counsellors: A century of proposals for change. Professional School Counseling, 5(4), 220-234.

Herr, E. L., Cramer, S. H., \& Nile, S. G. (2004). Career guidance and counselling through the lifespansystematic approaches $\left(6^{\text {th }} \mathrm{ed}\right.$.) London: Prentice Hall.

Herr, E. L., Savickas, M. L., \& Esbroeck, R. (2005). The internationalizion of educational and vocational guidance. The Career Development Quatrterly, 54, 77-85.

Holland, J. L. (1997). Making vocational choices. Odbessa, FL: Psychological Assessment Resources.

Holland, J. L., Daiger, D. C., \& Power, P. G. (1980). My vocational situation: Description of an experimental diagnostic form for the selection of vocational assistance. Palo Alto, CA: Consulting Psychologists Press.

Ibara, H. (2004). Identity transitions: Possible self, liminality and dynamics of career change. INSEAD Working Paper.

Kampelmann, S., \& Rycx, F. (2012). The impact of educational mismatch on firm productivity: Evidence from linked panel data, Economics of Education Review, $\quad$ Elsevier, 31(6), 918-931.

King, Z. (2003). New or traditional careers? A study of UK graduates' preferences. Human Resource Management Journal, 13(1), 5-26. DOL: 10.1111/j.17488583.2003.tb00081.x.

Kuijpers, M., Schyns, B., \& Scheerens, J. (2006). Career competencies for career success. Career Development Quarterly, 55 (2), 168-179.

Kunnen, S. E. (2013). The effect of career choice guidance on identity development. Hindawi: Hindawi Publication Corporation. 
Makinde, O. (1990). Fundamentals of guidance and counselling. London: Macmillan Education Ltd.

May, A. I. A., Arogundadade, B., \& Ekundayo, H. T. (2007). Assessing realities and challenges of technical education in Imo State Secondary School Education System. Nigeria Journal of Educational Administration and Planning. 7(1), 59- 64.

Maze, R. (2000). Parents push college over service. Army Times, 62(42), 24. Retrieved from http://ehostvg6.e...learn Term=vocational\%guidance

Mcglynn, A. P. (2007). Achieving the dream-what is it, and what's new? The Hispanic

Outlook in Higher Education, 18(4), 44-45.

Meijers, F., \& Wardekker, W. (2002). Career learning in a changing world: the role of emotions. International Journal for the Advancement of Counselling, 24 (3), 149167.

Momoh, O. A (2012). Revitalization of technical education in Nigeria as a vehicle for transformation. Proceedings of COREN 21st Engineering Assembly, 53-81.

Morgan, M. (2003). Australian blueprint for career develop: Draft Prototype. WA, Sydney: Subiaco.

Nurmi, J. M. E., \& Seginer, R. (1995). Tracks and transitions-A comparism of adolescents' future-oriented goals, exploration and commitments in Australia, Israel and Finland. International Journal of Psychology, 30,355-375.

Olamide, S. O., \& Olawaiye, S. O. (2013). The factors determining the choice of career among secondary school students. The International Journal of Engineering and

Science (IJES) 26, 33-44

Olayinka, M. S. (1973). Job aspirations of the youth and the educational provisions in Lagos. West African Journal of Education, XVII, (1), 41-49.

Onumah, K. (1992). Guidance and Counselling needed in schools. People's Daily Graphic, p. 7.

Opolot, J. K., \& Enon, J. C. (1990). Occupational aspirations of secondary schools leavers in Uganda and the link of these aspirations to job attainment process. Kutera project, IDRC Centre File, 3-p-86.

Osipow, S. (1990). Convergence in theories of career choice and development: Review and prospect, Journal of Vocational Behaviour, 36, 11-16.

Patton, M. C. (2002). Qualitative research and evaluation methods, ( $3^{\text {rd }}$ ed.) Thousand Oaks, CA: Sage publications.

Picus, L. O., Odden, A., \& Fermanich, M. (2003). A professional judgement approach to school finance adequacy in Kenturky. Paper prepared for the Kentucy department of education. Los Angeles: Picus and Associates.

Patton, M. C. (2002). Qualitative research and evaluation methods, ( $3^{\text {rd }}$ ed.) Thousand Oaks, $\quad$ CA: $\quad$ Sage publications.

Power, R. (2017). Why career failure is essential to your personal growth. Retrieved from http://www.inc.com/rhett-power-failure-is-good-for-personalgrowth:html 
Punch, E., Creed, P. A., \& Hyde, M. (2006). Predicting career development in hard-of hearing adolescents in Australia. Journal of Deaf Studies and Deaf Education, 10 (2), 146-160.

Richardson, M. L. (1993). Work in people's life: A location for counselling psychologists. Journal of Counselling Psychology, 40, 425-433.

Robbins, A. (2006). The over achievers: The secret lives of driven kids. Hachette Journal, 40, 425-433.

Salmela-Aro, K., \& Upadyaya, K. (2012). The school work engagement inventory: Energy, dedication and absorption. European Journal of Psychological Assessment, 28, 60-67.

Savickas, M. L. (1997). Career adaptability: An integrative construct for life-span, life space theory. Career Development Quarterly, 45, 247-259.

Savickas, M. L. (2001). A developmental perspective on vocational behaviour: career patterns, salience, and themes. International Journal for Educational and Vocational Guidance, 1, 49-57.

Savickas, M. L. (2002). Career construction. In D. Brown, \& Associate (Eds.), Career choice and development ( $4^{\text {th }}$ ed., pp. 149 - 205). San Francisco, CA: Jossey Bass.

Savickas, M. L. (2005). The theory and practice of career construction: In S.D. Brown \& R.T. Lent (Eds.), Career development and counselling: Putting theory and research to Work (pp. 42-70). Hoboken, N. J: Wiley.

Schwartz, S. J. (2012). The evolution of Eriksonian and, neo-Ericksonian identity theory and research: A review and integration, identity. International Journal of Theory and Research, 1(1), 7-5.

Schwartz, S. J., Cote. P., \& Arnett, J. J. (2005). Identity and agency in emerging adulthood. Youth and Society, 37, 201-229.

Sheeny-Skeffington, J., \& Rea, J (2017). How poverty affects decision-making process. York: Joseph Rowntree Foundation.

Sidney, P., \& Marland, J. R. (1971). Career education now. Sage Journal, 55(355), 1-11.

Super, D. E. (1990). A life-span, life- space approach to career development. In D, Brown and L. Brooks (Eds.), Career choice and development: Applying contemporary approaches to practice ( $2^{\text {nd }}$ ed., pp.197-261). San Francisco, CA: Jossey-Bass.

Super, D. W. (1980). A life-span, life-space approach to career development. Journal of Vocational Behaviour, 16, 282-298.

Tsipor, F. (2014). Just understand me: Four temperaments. Accra: Imprint Press.

UN. (2006). Committee on the Human Rights of the Child: Report of the Fourth-Second Session. Geneva: UN.

United Nations (2015). A blueprint to achieve a better and more sustainable future for all by 2030. New York: UN.

UNESCO (2015). Education 2030 Incheon Declaration and Frameworkfor Action: Towards inclusive and equitable quality education and lifelong learning for all. Paris, Retrieved from http://www.unesco.org/new/en/education/themes/leading-the-internationalagenda/educationforall/education-2030-fc 
West African Examinations Council (2017). Results statistics. Retrieved from hppt:/ghanadirect.org

WiseGeek.com (2013). What is occupational health policy? Retrieved from http://www.wisegeek.com/what-is-occupational-health-policy.htm.

Wyness, G., McGuigan, M. \& McNally S. (2016). Student awareness of costs and benefits of educational decisions: Effects of an information campaign. Journal of Human Capital, 10, (10), 482-519.

Zunker, V. G. (2002). Career counselling: Applied concept of life planning ( $6^{\text {th }}$ ed). Bruce/Cole, Califonia: Pacific Grove. 